\title{
Dampak Jenis dan Kualitas Gabah Mempengaruhi Tingkat Harga Gabah dalam Perspektif Ekonomi Syariah di Desa Talungeng Kecamatan Barebbo Kab. Bone
}

\author{
Wiwijianti \\ Institut Agama Islam Negeri (IAIN) Bone \\ wwijianti@yahoo.co.id \\ Agussalim \\ Sekolah Tinggi Agama Islam (STAl) Al -Furqan Makassar \\ Agussalimgm@gmail.com
}

\begin{abstract}
This study discusses the Impact of Grain Types and Quality Affecting Grain Levels in a Sharia Economic Perspective in Talungeng Village, Barebbo District, Kab. Bone, with the aim of research is to know the impact of grain type and quality affecting the level of grain prices and know the Islamic economic review of the impact of grain type and quality. The results showed that the impact of grain type and quality was very dependent on the selection of rice seeds / seeds to be planted in the fields, because of the variety of species favored by farmers, some were short-term and resistant to paddy disease. The names of seeds are: 66, Impari, Cengelis, and Celiung. While the quality depends on the way of maintenance in terms of providing fertilizer, poisons and water supply. Whereas in sharia economics the type and quality of grain is discipline and honesty of farmers in managing rice fields so that they are able to produce rice that fits the needs of the community and has a blessing value in it.
\end{abstract}

Keywords: Grain Type and Quality, Grain Price Level, Sharia Economic Perspective

\begin{abstract}
Abstrak
Penelitian ini membahas tentang Dampak Jenis dan Kualitas Gabah Mempengaruhi Tingkat Gabah Dalam Perspektif Ekonomi Syariah Di Desa Talungeng Kecamatan Barebbo Kab. Bone, dengan tujuan penelitian yaitu untuk mengatahui dampak jenis dan kualitas gabah mempengaruhi tingkat harga gabah dan mengatahui tinjauan ekonomi syariah terhadap dampak jenis dan kualitas gabah. Hasil penelitian menunjukan dampak jenis dan kualitas gabah adalah sangat bergantung pada

Jurnal Ilmiah Al Tsarwah Program Magister Program Studi Ekonomi Syariah

Institut Agama Islam Negeri (IAIN) Bone


pemilihan bibit/benih padi yang akan ditanam disawah, karena itu bermacam-macam jenis disukai petani, ada yang jangka pendek dan tahan dari penyakit sawah. Adapun nama bibit yaitup: 66, Impari, Cengelis, dan Celiung. Sedangkan kualitasnya tergantung pada cara pemeliharaan dalam hal pemberian pupuk, racun dan pemberian air. Sedangkan dalam ekonomi syariah jenis dan kualitas gabah yaitu kedisiplinan dan kejujuran petani dalam mengelolah sawah sehingga mampu menghasilkan beras yang sesuai kebutuhan masyarakat dan memiliki nilai berkah didalamnya.

Kata Kunci: Jenis dan Kualitas Gabah, Tingkat Harga Gabah, Perspektif Ekonomi Syariah

\section{PENDAHULUAN}

Kelangkaan sumber daya alam dapat di lihat dari harga barang sumber daya yang semakin meningkat maupun di lihat dari" royalty" atau"rent"adalah harga bayangan satu unit barang sumber daya yang ada dalam cadangan(stock).Bila seseorang tertarik pada “kelangkaaan"maka "rent"lebih cepat sebagai alat pengukurnya. ${ }^{1}$

Indonesia adalah negara kepulauan dengan berbagai ragam suku bangsa dan tradisinya.tetapi,secara nasional,bahwa justru dengan keragaman tersebut akan memperkaya kebudayaan nasional.di samping keragaman tersebut akan memperkaya kebudayaan nasional. Di samping keragaman dari masyarakat desa yang tentunya diseakan oleh pengaruh dalam (endogen) maupun pengaruh luar (eksogen), seperti keadaan alam, iklim dan tingkat kesuburan tanah.

Untuk lebih mendalami lebih tentang masyarakat desa maka ada baiknya dikupas tentang sikap mental masyarakat desa, dengan maksud 
agar dapat dilaksanakan perubahan-perubahan dalam rangka pembangunan,yang lebih terarah. ${ }^{2}$

Pertanian merupkan sumber kehidupan bagi sebagian besar penduduk negara berkembang seperti Indonesia. Padi merupakan produk pertanian pangan yang utama dalam upaya pemenuhan kebutuhan pangan nasional dan memberikan lapangan pekerjaan bagi sebagaian penduduk Indonesia. Beberapa faktor yang menyekan pentingnya keberadaan padi di Indonesia antaranya (1) proses produksi beras menyediakan kesempatan kerja bagi 21 juta keluarga petani, (2) beras merupakan bahan pangan pokok bagi sekitar 95 persen penduduk Indonesia, dan (3) sekitar 30 persen dari total pengeluaran rumah tangga miskin dialokasikan membeli beras. Peran tersebut menyekan gejolak harga akan berdampak pada pendapatan petani dan jumlah keluarga miskin di Indonesia. ${ }^{3}$

Kesejahteraan petani yang menjadi sasaran oembanguna pertanian perlu diperhatikan lebih serius. Petanai sebagai pelaku yang berperan dalam meningkatkan produksi seharusnya mendapatkan perhatian terutama dari pemerintah. Petani selalu menjadi pihak yang dirugikan, dengan biaya produksi yang tinggi, tetapi tidak diimbangi dengan harga jual hasil panen yang tinggi sehingga pendappatan petani tidak meningkat atau bahkan tidak cukup untuk kebutuhan hidup sehari-hari mereka. ${ }^{4}$

Tanah di dunia ini oleh USDA (United State Depertemen of Agricultural) dalam buku"Poerwowidodo Mas'ud" dikelompokkan ke dalam dua kelompok ordo,yaitu.

${ }^{2}$ Nyoman Beratha, Teknologi Desa (Ghalia Indonesia; Jakarta Timur, 1986)0, h. $22-23$

${ }^{3}$ Deli Sopian, "Analisis Harga Gabah dan Tingkat Pendapatan Petani Di Lokasi Program Dana Penguatan Modal Lembaga Usaha Ekonomi Pedesaan (LUEP)",Skripsi,Institut Pertanian Bogor, 2008, h. 14

${ }^{4}$ Ibid,h.18

Jurnal Ilmiah Al Tsarwah

Program Magister Program Studi Ekonomi Syariah 
1. Kelompok ordo tanah pelican, terdiri dari : Alfisol, Aridisol, Entisol, Inseptisol, Molisol, Oksisol, Spondosal, Ultisol dan Vertisol.

2. Kelompok ordo tanah organik, terdiri dari.Histosol. ${ }^{5}$

Pembagian kelompok ordo tanah ini hanya di dasarkan pada perbedaan jenis bahan induk. Ordo-ordo tanah pelican mempunyai bahan induk yang berasal dari bantuan, sedangkan ordo tanah organik mempuyai bahan induk yang berasal dari sisa-sisa organic

Hasil peruraian bantuan dari bahan organik adalah senyawasenyawa kimiawi.selama proses pembentukan tanah, terbentuk berbagai paduan khas senyawa kimiawi yang memungkinkan perkembagannya berbagai ordo tanah. Berdasarkan konsep ini maka tanah merupakan kumpulan senyawa kimiawi dalam berbagai wujud, watak dan perangai hasil pemecahan atau peruraian bahan induk tanah dengan melibatkan berbagai proses. ${ }^{6}$

Berdasarkan latar belakang di atas, maka ada beberapa masalah yang akan di angkat sebagai berikut Bagaimana Dampak Jenis dan Kualitas Gabah Mempengaruhi Tingkat Harga Gabah Di Desa Talungeng Kecamatan Barebbo, dan Bagaimana Tinjauan Ekonomi Syariah Terhadap Dampak Jenis dan Kulaitas Gabah Mempengaruhi Tingkat Harga Gabah Di Desa Talungeng Kecamatan Barebbo.

${ }^{5}$ Poerwidodo Mas'ud, Telaah Kesuburan Tanah (Cet.IV ; Angkasa : Bandung, [t. Th]), ${ }^{6} \mathrm{lbid}$ 


\section{METODE}

\section{Lokasi dan Jenis Penelitian}

\section{a. Lokasi Penelitian}

Penelitian ini beralokasi di Desa Talungeng Kecamatan Barebbo Kabupaten Bone. Di Lingkungan Talungeng memiliki 3 lingkungan yaitu : Lingkungan Teko-Teko, Lingkungan Galung, dan Lingkungan Talungeng.

b. Penelitian ini adalah penelitian lapangan dengan menggunakan pendekatan kuantitatif. Sedangkan desain penelitian yang digunakan adalah desai deskriptif kualitatif menurut Aake desain pennelitian adalah perencanaan terinci yang mengaraah pada tujuan dari penelitian tersebut. ${ }^{7}$

Sedangkan tujuan desain penelitian deskriptif kualitatif adalah untuk mengembangkan, meringkaskan berbagai kondisi, fenomena realitas yang ada di masyarakat yang menjadi objek penelitian, dan berupaya menarik realitas itu sebagai suatu ciri, karakter, sifat model, tanda, atau gambaran tentang kondisi, situasi, atau fenomena tertentu. ${ }^{8}$ Berdasarkan penjelasan di atas maka dalam penelitian yang dilakukan ini, desain deskriptif kualitatif dugunakan untuk menggambarkan kondisi Masyarakat Tani di Lingkungan Talungeng dengan mengatahui Jenis dan Kualitas padi.

\section{Pendekatan Penelitian}

Pendekatan penelitian yang digunakan dalam penelitian ini adalah pendekatan kualitatif. Pendekatan kualitatif ini merupakan pendekatan yang memusatkan perhatian pada prinsip-prinsip umum yang mendasari perwujudan sebuah makna dari gejala-gejala sosial masyarakat untuk

h. 24

${ }^{7}$ Aaker, dkk, Marketing Research (Hawkin : Mac. Millan Publishing Compani, 2001),

${ }^{8}$ Burhan Mungin, Penelitian Kualitatif: Komunikasi, Ekonomi, Kebijakan Publik dan IImu Sosial Lainnya (Jakarta : Prenada Media Group, 2008), h. 68 
mendapatkan gambaran umum mengenai kategorisasi tertentu. ${ }^{9}$ Menurut Bogdan dan Taylor mendefenisikan metodologi kualitatif sebagai prosedur penelitian yang menghasilkan data deskriptif berupa kata-kata tertulis atau lisan dari orang-orang dan perilaku yang diamati. Dalam penelitian kualitatif ini, metode yang biasanya di manfaatkan adalah wawancara, pengamatan, dan pemanfaatan dokumen. ${ }^{10}$

\section{Data dan Instrumen Pengumpulan Data}

Pengumpulan data dilakukan untuk memperoleh informasi yang dibutuhkan dalam rangka mencapai tujuan penelitian. Dalam hal ini, jenis data yang digunakan pada penilitian ini, yaitu:

a. Data primer

Data primer merupakan data yang didapat dari sumber pertama baik dari individu atau perorangan. ${ }^{11}$ Data primer yang digunakan dalam penelitian ini, diperoleh secara langsung dari obyek/subyek penelitian.

b. Data sekunder

Menurut sudjana yang dikemukakan Ardiyana bahwa data sekunder yaitu yang diperoleh secara tidak langsung dari sumbernya dan bukan diusahakan sendiri oleh penulis atau peneliti. Data sekunder yang digunakan dalam penelitian ini, yaitu data dokumentasi dari dinas terkait, dan buku-buku yang menunjang penelitian ini. ${ }^{12}$

\section{Teknik Analisis Data}

Untuk menganilisis data yang diperoleh dari berbagai sumber, dengan menggunakan teknik pengumpulan data yang bermacam-macam

\footnotetext{
${ }^{9}$ lbid h. 306

${ }^{10}$ Lexy J. Moeleong, Metodologi Penelitian Kualitatif (Ed. Revisi, Cet. 20 ; Bandung :
} PT Remaja Rosdakarya Bandung, 2004), h. 4-5

${ }^{11}$ Husein Umar, Op Cit, h. 8

${ }^{12}$ Marissa Ardiyana, "Analisis Perbandingan Kinerja Keuangan Bank Syariah Dan Bank Konvensional Sebelum, Dan Sesudah Krisi Tahun 2008 Dengan Menggunakan Metode Camel (Studi Kasus Pada PT. Bank Syari'ah Mandiri Dan PT. Bank Mandiri Tbk)", Skripsi, Universitas Diponegoro, Semarang, 2011, h.33 
(trianggulasi), yang dilakukan secara terus menerus sampai datanya jenuh. ${ }^{13}$ Maka teknik analisis yang digunakan bersifat indukatif. Menurut Mile dan Huberman (1948) yang dikemukakan Sugiyono bahwa aktivitas dalam analisis data kualitatif dilakukan dengan cara interktif dan berlangsung secara terus menerus sampai tuntas, sehingga datanya sudah jenuh. Aktivitas dalam analisis yaitu:

a. Data Reduction (reduksi data) adalah merangkum, memilih hal-hal yang pokok, memfokuskan pada hal-hal yang penting, dicari tema polanya.

b. Display Data (penyajian data) penyajian data yang dilakukan dalam bentuk table, grafik, phie chard, pictogram dan sejenisnya.

c. Consultion Drawing (verification) menurut data yang dilakukan Miles dan Huberman adalah penarikan kesimpulan dan verifikasi. Kesimpulan awal yang dikemukakan masih bersifat sementara, dan akan berubah bila tidak temukan bukti-bukti yang kuat yang mendukung pada tahap pengumpulan data berikutnya. ${ }^{14}$

\section{HASIL DAN PEMBAHASAN}

Dalam masyarakat Tani Desa Talungeng pada saat melakukan pemanenan mereka harus mengeluarkan upah dari hasil panen padi itu, tidak seberapa yang dikeluarkan petani untuk sebagai upah pada saat panen. Karena sekarang ini kurangnya pekerja yang mana dulunya pemilik itu sendirilah yang memanennya. Tapi saat ini mereka tidak mampu lagi melakukan sehingga mereka harus mempekerjakan orang yang membutuhkan uang tambahan untuk memenuhi tambahannya. Namun sebagaian besar masyarakat Talungeng menggunakan alat canggih untuk

${ }^{13}$ Nasution, Metodologi Research Penelitian Ilmiah (Jakarta: Bumi Aksara, 2000), h.

${ }^{14}$ Ibid, h. 404-412

Jurnal Ilmiah Al Tsarwah

Program Magister Program Studi Ekonomi Syariah

Institut Agama Islam Negeri (IAIN) Bone 
memanen padinya misalnya mobil yang mampu memotong padi dan langsung terpisah dari tangkainya, dan juga langsung dalam kemasan. Berbeda dengan pemanenan manual karena harus menggunakan tenaga dan menjadi butuh waktu yang cukup lama untuk menyelesaikan semua. ${ }^{15}$

Menurut Muh. Ali RT 03 Talungeng, setiap kali panen dia hanya menghasilkan 30 karung saja, kemudian upah yang diberikan kepada pekerja hanya 1 karung saja dengan harga Rp. 120.000,- kemudian beliau menjualnya 10 karung dan dari hasil penjualan dia memperoleh hasil jualannya sekitar Rp. 1.200.000,- yang tersisa 20 karung, termasuk persiapan konsumsi rumah tangga oleh keluarganya. ${ }^{16}$

Sistem pemanenan dilakukan dua kali dalam satu tahun, yang pertama masyarakat menggarap sawah pada bulan Mei dan panen di bulan September, yang kedua masyarakat menggarap lagi sawah pada bulan November dan panen di bulan Maret. Dalam proses penanaman sebagian masyarakat memilih jenis padi Cengelis untuk ditanam.

a. Kenaikan Harga Gabah

Kenaikan harga gabah/padi bergantung kualitas dan kuantitas beras yang dipengaruhi oleh cuaca serta jenis dan cara penggunaan pupuk. Serta kadar air yang terdapat padi yang baru panen. Sehingga sangat mempengaruhi kualitasnya. Selain itu ada pula yang menyekan kenaikan harga yaitu kurangnya pembeli gabah atau kurangnya permintaan.

\section{b. Persaingan Harga dalam Pasar}

Dalam jual beli yang dilakukan dipasar kadang terjadi kenaikan harga, sehingga terjadi persaingan antar penjual. Seringkali terjadi penawaran yang jauh dibawah standar harga antara pembeli dan penjual,

15 Firdaus, Petani Desa Talungeng Kecamatan Barebbo Kabupaten Bone, "Wawancara", Desa Talungeng, Tanggal, 14 Oktober 2016.

${ }^{16}$ Muh. Ali, Ketua RT 03 Desa Talungeng Kecamatan Barebbo Kabupaten Bone, "Wawancara", Desa Talungeng, Tanggal, 14 Oktober 2016 
sehingga pembeli meminta harga yang jauh dari harga yang ditawarkannya, maka dari situ pula sering terjadi persdaingan antar penjual.

Jual beli dalam konsep Islam berdasarkan atas keridhoan kedua belah pihak (penjual dan pembeli).

Harga suatu barang adalah tingkat pertukaran barang dengan barang lain. Harga terbentuk dan kompetensi produk untuk memenuhi tujuan dan pihak, yaitu produsen dan konsumen. Produsen memandang harga sebagai nilai barang yang mampu memberikan manfaat keuntungan diatas biaya produksinya (atau tujuan lain, misalnya keuntungan).

c. Harga Dalam Persaingan Sempurna Pada Pasar Islami

Dalam konsep Islam, yang paling prinsip adalah harga ditentukan oleh keseimbangan permintaan dan penawaran. Keseimbangan ini terjadi bila antara penjual dan pembeli bersikap saling merelakan. Akan tetapi apabila para pedagang sudah menaikkan harga di atas batas kewajaran, mereka itu telah berbuat zalim dan sangat membahayakan umat manusia. Maka seorang penguasa (pemerintah) harus campur tangan dalam menangani persolan tersebut dengan cara menetapkan harga standar.

Penetapan harga dasar gabah oleh pemerintah Indonesia sampai saat ini, baik pada musim panen raya maupun masa peceklik berarti bertentangan dengan konsep ekonomi Islam. Penetapan harga dasar gabah menurut harga pasar akan turun dari biasanya, namun karena adanya intervensi pemerintah dengan menetapkan harga dasar gabah maka harga gabah akan naik dari harga pasar. ${ }^{17}$

Islam sebagai agama Allah SWT yang sempurna memberikan petunjuk kepada manusia tentang bidang usaha yang halal, cara berusaha, dan bagaimana manusia harus mengatur hubungan kerja dengan sesame

17 Sasli Rais dan Wakhyudi, "Kebijakan Penetapan Harga Dasar Gabah Di Indonesia : Kajian Ekonomi Islam”, “Skripsi”, Akses Tanggal, 14 Oktober 2016, h. 27

Jurnal Ilmiah Al Tsarwah Program Magister Program Studi Ekonomi Syariah 
mereka supaya memberikan manfaat yang baik baik kepentingan bersama dan dapt menciptakan kesejahteraan serta kemakmuran hidup bagi segenap manusia. Islam tidak hanya menyuruh manusia bbekrja bagi kepentingan dirinya sendiri secara halal, tetapi juga memerintahkan manusia menjalin hubungan kerja dengan orang lain bagi kepentingan dan keuntungan kehidupan manusia dijagat raya ini. Oleh karena itu, dalam bidang usaha dan wiraswasta Islam benar-benar memberikan petunjuk-petunjuk yang jelas untuk dapat dijadikan pedoman melakukan usaha dan wiraswasta yang baik .

Ketentuan Islam yang jelas mengenai bidang jual beli, bebagai bentuk usaha, untuk memberikan pedoman kepada manusia dalam melakukan aktivitas tersebut guna menciptakan kehidupan pribadi dan masyarakat yang adil, bermartabat, dan saling menolong sehingga tercipta kesejahteraan dan kemakmuran bersama,

Bahkan sabda Nabi, "Sesungguhnya bekerja mencari rizki yang halal merupakan kewajiban setelah ibadah fardlu" (HR. Ttabrani dan Baihaqi).

Sebagaimana diketahui bahwa Allah SWT telah menjadikan manusia dengan berbagai naluri, diantaranya naluri hidup bermasyarakat. Naluri ini memberikan kepada manusia untuk membutuhkan orang lain dalam menebuh kehidupan sehari-hari mereka, dan pada dasarnya kebutuhan ini berhubungan deengan urusan kemasyarakatan. Oleh se itu, manusia tidak dapat hidup sendiri tanpa bantuan pertolongan dari orang lain.

Dengan demikian, untuk mengatur dalam hal urusan kemasyarakatan harus dikenal hokum-hukum dan aturan-aturan dalam Islam itu sendiri. Sejalan dengan perdagangan atau surat usaha yang sejak dahulu dan terus berkembang hingga sekarang, dimana manusia telah berinteraksi satu sama lain untuk memenuhi kebutuhan hidupnya. Semakmur apa pun hidup 
masyarakat masih tetap membutuhkan suatu usaha yang menunjang kehidupan kedepannya. ${ }^{18}$

Pekerjaan berdagang atau jual beli mendapat tempat terhormat dalam ajaran Islam, seperti di sabdakan Rasul. Mata pencarian apa yang paling baik, Ya Rasulullah?" jawab beliau: seseorang yang bekerja dengan tangannya sendiri dan setiap jul beli yang bersih," (HR. Al-Bazzar).

Dalam (QS. Al-Baqarah:275) dijelaskan bahwa Allah swt telah menghalalkan kegiatan jual beli dan mengharamkan riba.

$$
\text { وَأَحَلَّ السلهُ الْبَيْعَ وَحَرَّمَ الرِّبَا }
$$

Terjemahannya:

"Allah telah meghalalkan jual beli dan mengharamkan riba". ${ }^{19}$

Kegiatan riba ini sangat merugikan karena membuat kegiatan jual beli tidak berkembang. Hal ini disekan karena uang dan modal hanya berputar pada satu pihak saja yang akhirnya dapat mengeksploitasi masyarakat yang terdesak kebutuhan hidup. ${ }^{20}$

Jual beli merupakan akan yang umum digunakan oleh masyarakat, karena pada setiap pemenuhan kebutuhannya, masyarakat tidak biasa berpaling untuk meninggalkan akad ini, untuk mendapatkan makanan dan minuman misalnya, terkadang ia tidak mampu untuk memenuhi kebutuhan itu dengan sendirinya, tapi akan membutuhkan dan berhubungan dengan orang lain, sehingga kemungkinan besar akan terbentuk akad jual beli.

Jual beli dapat ditinjau dari beberapa segi. Ditinjau dari segi hukumnya, jual-beli ada dua macam yaitu jual-beli yang sah menurut hukum dan batal menurut hukum, dari segi objek jual beli dan segi pelaku jual beli.

${ }^{18}$ Asyraf M, Dawabah, Menjadi Pengusaha Muslim (Cet. 1, Jakarta: Pustaka AlKausar, 2005), h. 36

${ }_{19}$ Op. Cit, h. 47

20 Hulwati, M.Hum, Ekonomi Islam Teori dan Prakteknya dalam Perdagangan Ed ; 1 (Padang: Ciputa Press Group, 2006), h.15 
Kemudian dijelaskan pula dalam firman Allah SWT surah Al-Fatir 29 yang berbunyi:

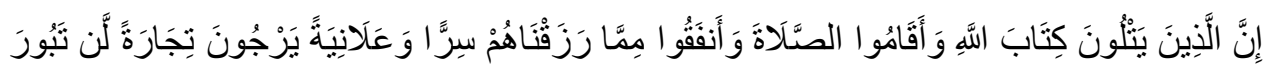

Terjemahannya:

"Sesungguhnya orang-orang yang selalu membaca kitab Allah dan mendirikan shalat dan menafkahkan sebahagian dari rezeki yang kami anugerahkan kepada mereka dengan diam-diam dan terang-terangan, mereka itu mengharapkan perniagaan yang tidak akan merugi".

Di dalam hukum Islam, hubungan itu dinamakan muamalah yang artinya segala peraturan yang diciptkan Allah untuk mengatur hubungan manusia dengan manusia dalam hidup dan kehidupan.

Syari'at Islam melindungi manusia untuk berniaga, dan menganjurkan untuk berjual beli dan aturan jual beli itu wajib ditaati. Tindakan penipuan akan merugikan masyarakat, dan hal ini akan mendorong manusia untuk mengurangi hak-hak orang lain dengan tipu daya muslihat dan tindakan tersebut akan menghancurkan system social masyarakat tertentu.

Tujuan Allah SWT, mengutamakan soal timbangan atau takaran dan ukuran dalam risalah Nabi Syu'aib bukan sekedar menimbang atau menimbun melainkan mendorong manusia untuk berbuat dan bertindak yang benar serta menjunjung tinggi hak-hak orang lain. Selain hal itu, Ilslam sebagai agama yang mengutamakan prinsip keadilan, menjunjung tinggi nilai persaudaraan antara sesame muslim, menegakkan kebenaran dan menghilangkan kebatilan. Islam mengatur seseorang dalam melakukan jual beli, yakni dituntut untuk adil dengan memenuhi takaran dan timbangan. Dengan demikian tidak ada salah satu pihak yang dirugikan. Bagi pelaku jual beli dilarang untuk mengurangi takaran atau yang ditakar dan juga dilarang mengurangi timbangan atau yang ditimbang. 
Allah telah menghancurkan satu umat dari umat-umat yang dulu mereka berbuat curang dalam takaran dan timbangan. Firman Allah Ta"ala, "kami tidak membebani seseorang melainkan menurut kesanggupannya." Artinya barang siapa yang bersungguh-sungguh dalam menunaikan yang hak dan mengambilnya, jika dia salah setelah mengerahkan kemampuannya maka tidak ada dosa baginya.

Penyempurnaan takaran dan timbangan oleh ayat diatas dinyatakan baik dan lebih bagus akibatnya. Ini karena menyempurnakan takaran atau timbangan melahirkan rasa aman, kjetentraman dan kesejahteraan hidup bermasyarakat. Ini tentu saja memerlukan rasa aman yang menyangkut alat ukur, baik takaran maupun timbangan. Siapa yang membenarkan bagi dirinya mengurangi hak seseorang, maka itu mengantarnya membenarkan perlakuan serupa kepada siapa saja, dan ini mengantar kepada tersebarnya kecurangan. Bila itu terjadi, maka rasa aman tidak akan tercipta, dan ini tentu saja tidak berakibat baik bagi perorangan dan masyarakat. ${ }^{21}$

\section{KESIMPULAN DAN SARAN}

\section{Kesimpulan}

a. Adapun dampak jenis gabah yaitu tergantung pada pemilihan bibit/benih padi yang akan ditanam disawah. Karena itu bermacammacam jenis yang disukai petani, ada yang berumur jangka pendek dan ada pula yang tahan dari penyakit seperti ada namanya bibit66, Cengelis, Impari dan Celiung.

${ }^{21}$ Mujiburrohman, "Tinjauan Hukum Islam Terhadap Jual Beli Tembakau Dengan Sistem Pengurangan Timbangan (Studi kasus di desa pitrosari, kecamatan wonobowo, kabupaten temanggung)", Skripsi, Universitas Islam Negeri Walisongo Semarang, Tahun 2015 
Sedangkam dampak kualitas gabah yaitu tergantung dari cara pemeliharaan dalam hal pemberian pupuk, racun dan pemberian air sehingga dapat menghasilkan kualitas gabah yang bekualitas tinggi.

b. Adapun analisis Ekonomi Syariah dalam hal jenis dan kualitas gabah yaitu kedisiplinan dan kejujuran petani dalam mengelolah sawah, sehingga dapat menghaslikan beras yang sesuai dengan kebutuhan masyarakat, serta memiliki nilai berkah di dalamnya.

Saran

Berdasarkan temuan dari penelitian ini, maka peneliti akan memberikan beberapa saran atau kritikan sekiranya bermanfaat bagi pembaca atau peneliti selanjutnya. Kepada Pejabat Desa Talungeng, kiranya memperhatikan masyarakat yang melakukan penanaman padi, seperti memberikan bantuan kepada warganya.

\section{DAFTAR PUSTAKA}

Asmuliani A, "Pengaruh Tebal Tumpukan Terhadap Mutu Benih (Oriza Sativa) Hasil Pengaruh Dengan Box Dryer",Skripsi, Universitas Hasanuddin, Makassar, 2012

Asyraf M, Dawabah, Menjadi Pengusaha Muslim (Cet. 1, Jakarta: Pustaka AlKausar, 2005)

Burhan Mungin, Penelitian Kualitatif: Komunikasi, Ekonomi, Kebijakan Publik dan IImu Sosial Lainnya (Jakarta : Prenada Media Group, 2008)

Darmanik, Theresia R., "Analisis Faktor-faktor yang Mempengaruhi Harga Jual Gabah Petani Di Serdabg Begadai", Alumni Departemen Agribisnis, Skripsi, Tanggal Akses, 23 Oktober 2016

Deli Sopian, "Analisis Harga Gabah dan Tingkat Pendapatan Petani Di Lokasi Program Dana Penguatan Modal Lembaga Usaha Ekonomi Pedesaan (LUEP)",Skripsi,Institut Pertanian Bogor, 2008 
Departemen Agama RI, Al-Qur'an dan Terjemahannya (Bandung : CV. Jumanatul ALI-ARY, 2004)

Departemen Pendidikan Nasional, "Kamus Besar Bahasa Indonesia" (Ed. 111 ; Jakarta :Belai Pustaka, 2002)

Fatimah, lbu Rumah Tangga Desa Talungeng Kecamatan Barebbo Kabupaten Bone "Wawancara", Desa Talungeng, tanggal, 22 Oktober 2016

Galih Nico Supramudho, "Efisiensi Serapan N Serta Hasil Tanaman Padi (Oriza Sativa L) Pada Berbagai Imbangan Pupuk Kandang Puyuh dan Pupuk Anorganik Di Lahan Sawah Palur Suharjo"'Skripsi, Universitas Sebelas Maret, Surakarta, 2008

Herawati, Budidaya Padi ( Cet. II ; Yogyakarta : Javalitera, 2013)

Hulwati, M.Hum, Ekonomi Islam Teori dan Prakteknya dalam Perdagangan

Ed ; 1 (Padang: Ciputa Press Group, 2006)

Irfan Abdulrachman Mubaroq, "Kajian Potensi Bionutrien Dengan Penambaha Lon Logam Terhadap Pertumbuhan dan Perkembahgan Tanaman Padi"Skripsi, Universitas Pendidikan Indonesia, 2013

Kemas Ali Hanafiah, M.S, Dasar-Dasar IImu Tanah, Ed. 1 (Cet. IV ; Jakarta : Rajawali Pers, 2010)

Lexy J. Moeleong, Metodologi Penelitian Kualitatif (Ed. Revisi, Cet. 20 ; Bandung : PT Remaja Rosdakarya Bandung, 2004), h. 4-5

Marissa Ardiyana, "Analisis Perbandingan Kinerja Keuangan Bank Syariah Dan Bank Konvensional Sebelum, Dan Sesudah Krisi Tahun 2008 Dengan Menggunakan Metode Camel (Studi Kasus Pada PT. Bank Syari'ah Mandiri Dan PT. Bank Mandiri Tbk)", Skripsi, Universitas Diponegoro, Semarang, 2011, h.33

Muhammad Abdul Mannan, Ekonomi Islam : Teori dan Praktek (Jakarta ; Intermasa, 19992)

Muh. Ali, Ketua RT 03 Desa Talungeng Kecamatan Barebbo Kabupaten Bone, "Wawancara", Desa Talungeng, 13 Oktober 2016. 
Muhammad Nizar H, "Pengaruh Beberapa Jenis Bahan Organik Terhadap Pertumbuan dan Hasil Tanaman Padi (Oriza Sativa L) Metode Sri (The System Of Rice Intensification)", Skripsi, Universitas Andalan, Padang, 2010 